\title{
Regulation of Calcium Homeostasis in Sensory Neurons by Bradykinin
}

\author{
Stanley A. Thayer, Teresa M. Perney, and Richard J. Miller \\ Department of Pharmacological and Physiological Sciences, University of Chicago, Chicago, Illinois 60637
}

\begin{abstract}
The nonapeptide bradykinin (BK) activates sensory neurons and stimulates the transmission of nociceptive information into the CNS. We investigated the effect of this peptide on rat dorsal root ganglion neurons (DRG) grown in vitro. BK stimulated the synthesis of inositol trisphosphate $\left(\mathrm{IP}_{3}\right)$ and the breakdown of phosphatidylinositol bisphosphate, the synthesis of diacylglycerol, and the release of arachidonic acid from DRG cells. The release of $I P_{3}$ and arachidonic acid was not inhibited by pretreatment of the cells with pertussis toxin. BK also mobilized intracellular $\mathrm{Ca}^{2+}$ stores in DRG cells as assessed by fura-2-based microfluorimetry. Two types of $\mathrm{Ca}^{2+}$ stores appeared to exist in DRG neurons. One type could be mobilized by caffeine $\left(10^{-2} \mathrm{M}\right)$, and this effect could be blocked by ryanodine in a use-dependent manner. These stores occurred primarily in the cell soma and were virtually absent from cell processes. A second type of store could be mobilized by BK, presumably through the mediation of $\mathbf{I P}_{3}$. These latter stores were distributed equally between the cell soma and processes. Experiments with combinations of caffeine and BK suggested that the stores mobilized by these 2 agents may be separate entities. Both the caffeine and BK sensitive $\mathrm{Ca}^{2+}$ storage sites appeared to participate in buffering a $\mathrm{Ca}^{2+}$ load induced in DRG neurons by cell depolarization. The relevance of these observations to the mechanism of action of BK on sensory neurons is discussed.
\end{abstract}

The nonapeptide bradykinin (BK) is released from its precursors the kininogens by the action of the enzyme kallikrein in response to trauma (Erdos, 1979). BK production is one of a number of responses to injury initiated by the activation of Hagemann factor-other examples being the blood clotting and complement fixation cascades. Receptors for BK exist in a number of tissues, including the nervous system (Manning and Snyder, 1983), gastrointestinal and vascular smooth muscle (Manning et al., 1986; Beny et al., 1987), the gastrointestinal mucosa (Manning et al., 1982) and many others. When such receptors are activated, a multitude of responses are initiated which help to orchestrate the body's defenses against injury.

BK powerfully activates sensory neurons (Higashi et al., 1982), leading to the increased release of neurotransmitters such as substance P (Yaksh and Hammond, 1982). These neurotrans-

Received Oct. 19, 1987; revised Jan. 28, 1988; accepted Mar. 22, 1988.

Supported by PHS Grants DA-02121, DA-02575, and MH-40165 and by grants from Miles Pharmaceuticals and Marion Labs. T.M.P. was supported by PHS Training Grant GM-07151. S.A.T. was supported by F32 NS-08009.

Correspondence should be addressed to Prof. Richard J. Miller, Ph.D., Department of Pharmacological and Physiological Sciences, University of Chicago, 947 E. 58th Street, Chicago, IL 60637.

Copyright (C) 1988 Society for Neuroscience $0270-6474 / 88 / 114089-09 \$ 02.00 / 0$ mitters mediate the transmission of nociceptive information into the spinal cord. Although such a role for BK is well established, the molecular mechanisms underlying these actions are obscure. In non-neuronal tissue, BK receptor activation leads to the stimulation of both phospholipase $\mathrm{C}$ and phospholipase $\mathrm{A}_{2}$ and the subsequent release of a host of powerful lipid-derived second-messenger molecules (Hong and Deykin, 1982; Miller, $1987 \mathrm{~b})$. These include inositol trisphosphate $\left(\mathrm{IP}_{3}\right)$, diacylglycerol (DAG), and arachidonic acid (Miller, 1987b). These substances can now initiate $\mathrm{Ca}^{2+}$ mobilization, activation of protein kinase $\mathrm{C}(\mathrm{PKC})$, and eicosanoid biosynthesis, which can, in turn, lead to the synthesis of further second messengers. Studies on neuronal clonal cell lines have indicated that BK can also stimulate the production of lipid-derived intermediates in neuronal tissues (Yano et al., 1984; Francel and Dawson, 1986; Francel et al., 1987; Jackson et al., 1987; Miller, 1987b; Van Calker and Heumann, 1987). Furthermore, various electrophysiological effects of BK and of lipid-derived second messengers have been demonstrated both in neuronal cell lines and authentic sensory neurons (Baccaglini and Hogan, 1983; Fowler ct al., 1985; Rciscr and Hamprecht, 1985; Higashida and Brown, 1986a, b, 1987; Higashida et al., 1986; Osugi et al., 1986a, b; Rang and Ritchie, 1987; Weinreich, 1986).

The release of neurotransmitters from sensory neurons can be triggered by increases in $\left[\mathrm{Ca}^{2+}\right]_{\mathrm{i}}$. In dorsal root ganglion (DRG) and other nerve cells, the resting $\left[\mathrm{Ca}^{2+}\right]_{i}$ is normally very low $\left(\simeq 10^{-7} \mathrm{M}\right)(\mathrm{Miller}, 1987 \mathrm{a}) \cdot\left[\mathrm{Ca}^{2+}\right]_{\mathrm{i}}$ can potentially increase either through $\mathrm{Ca}^{2+}$ influx from the cell exterior via a variety of membrane channels or by mobilization from intracellular $\mathrm{Ca}^{2+}$ stores (Miller, 1987a). In the present series of studies, we have examined the effects of BK on lipid metabolism and authentic sensory neurons in vitro. We find that BK activates phospholipases $\mathrm{C}$ and $\mathrm{A}_{2}$ and also modulates intracellular $\mathrm{Ca}^{2+}$ stores. Furthermore, sensory neurons seem to possess a $\mathrm{Ca}^{2+}$ store that can be mobilized by methylxanthines such as caffeine. The properties of the BK and caffeine-sensitive stores are compared.

\section{Materials and Methods}

Cell culture. Pure populations of DRG neurons were cultured as described by Perney et al. (1986). Briefly, DRG neurons were dissected from thoracic and lumbar segments of 1 - to 3-d-old Sprague-Dawley rats, incubated for $15 \mathrm{~min}$ at $37^{\circ} \mathrm{C}$ in collagenase/dispase $(0.8$ and 6.4 units $/ \mathrm{ml}$ ), and then dissociated into single cells by trituration through a Pasteur pipette. The cells were then plated on laminin-fibronectincoated coverglasses (no. 1, $25 \mathrm{~mm}$ diameter). Cells were fed every 2-3 d with Ham's nutrient mixture F-12 supplemented with $5 \%$ heat-inactivated rat serum, $4 \% 17-\mathrm{d}$ embryonic rat extract, $50 \mathrm{ng} / \mathrm{ml} \mathrm{NGF}, 44$ mM glucose, $2 \mathrm{~mm}$ L-glutamine, $1 \%$ MEM $100 \times$ vitamins (GIBCO), and penicillin/streptomycin (100 units $/ \mathrm{ml}$ and $100 \mu \mathrm{g} / \mathrm{ml}$, respectively; GIBCO). Cultures were maintained at $37^{\circ} \mathrm{C}$ in a water-saturated atmosphere with $5 \%$ carbon dioxide. Sympathetic neurons were cultured 
from rat superior cervical ganglia (Perney et al., 1986) and central neurons from rat striatum (Murphy et al., 1987). Cultures were treated with $10^{-5} \mathrm{M}$ cytosine arabinoside for $48 \mathrm{hr}, 12 \mathrm{hr}$ after plating to suppress the growth of non-neuronal cells.

Measurement of $\left[\mathrm{Ca}^{2+}\right]_{r}$. $\left[\mathrm{Ca}^{2+}\right]_{\mathrm{i}}$ was determined using a microfluorimeter to monitor $\mathrm{Ca}^{2+}$-sensitive fluorescent chelator, fura-2 (Grynkiewicz et al., 1985). Neurons were loaded with the dye by incubation with 2 $\mu_{\mathrm{M}}$ fura-2 acetoxymethyl ester (Molecular Probes Inc., Eugene, OR), which is membrane permeant, for $1 \mathrm{hr}$ at $37^{\circ} \mathrm{C}$ in HEPES-buffered Hank's balanced salt solution, $\mathrm{pH} 7.45$, containing $0.5 \%$ BSA. The HEPES Hank's solution was composed of (in $\mathrm{mm}$ ) the following: HEPES, $20 ; \mathrm{NaCl}, 137 ; \mathrm{CaCl}_{2}, 1.3 ; \mathrm{MgSO}_{4}, 0.4 ; \mathrm{MgCl}_{2}, 0.5 ; \mathrm{KCl}, 5.0 ; \mathrm{KH}_{2} \mathrm{PO}_{4}$, $0.4 ; \mathrm{NaHPO}_{4}, 0.6 ; \mathrm{NaHCO}_{3}, 3.0$; and glucose, 5.6. Following the loading incubation, during which time the dye ester is hydrolyzed by cytosolic esterases to the membrane-impermeant polycarboxylate anion that is fura-2, the cells were washed twice in the HEPES-Hank's solution and incubated for $30 \mathrm{~min}$. It is difficult to measure precisely the amount of dye loaded into a cell. However, in cells loaded with a $100 \mu \mathrm{M}$ fura-2 via internal dialysis with a patch-clamp pipette, the fluorescence signal was similar to the very brightest cells used in this study. Thus, $100 \mu \mathrm{M}$ would be an upper limit for the intracellular fura-2 concentration.

The coverglasses containing the loaded and washed cells were then mounted in a flow-through chamber for viewing. Briefly, the chamber consisted of a Plexiglas block machined to accommodate the coverslip as a bottom. Three reservoirs were cut into the block such that a thin sheet of buffer flowed out of the inlet reservoir, across the cells in the experimental chamber, and was drawn up across nylon mesh to the efflux reservoir for evacuation by suction. Solutions in the chamber could be completely exchanged within $15 \mathrm{sec}$, including the time taken to flow through the tubing delay between the large media reservoirs and the inlet to the chamber. Experiments were run at $22^{\circ} \mathrm{C}$.

The perfusion chamber was mounted on an inverted microscope (Diaphot, Nikon, Garden City, NY), and cells and processes were localized by standard phase-contrast illumination. The perfusion chamber as well as the microfluorimeter are described in detail elsewhere (Thayer et al., 1987a, 1988). For excition of the fura-2, the collimated light beam from a $200 \mathrm{w} \mathrm{Hg}$ arc lamp was passed through a dual-beam spectrophotometer (Phoenix Instruments), which alternated wavelengths from 340 to 380 $\mathrm{nm}$ by means of a wheel spinning at a frequency of $60 \mathrm{~Hz}$. In place of the original sample chamber, a collimating beam probe was placed for focusing the light onto the end of a liquid guide $(3 \mathrm{~mm} \times 1 \mathrm{~m}$, Oriel, Stratford, CT). On the other end of the liquid light guide, a similar probe was positioned for directing light through the epifluorescence illuminator of the microscope. The light was reflected off a dichroic mirror (Nikon, DM 400) and through a $\times 70$ phase-contrast oil-immersion objective (E. Leilz nc., Rockleigh, NJ, numerical aperature, 1.15). The emission fluorescence was selected for wavelength with a $480 \mathrm{~nm}$ barrier filter, and recordings were defined spatially with a rectangular diaphragm. The fluorescence emission was analyzed with a photomultiplier tube and discriminator (Thorn EMI Gencom Inc., Plainview, NY). The discriminator output was converted to pulses, which were then integrated by passing the signal through an 8-pole low-pass Bessel filter at $500 \mathrm{~Hz}$. The photomultiplier signal was fed into one channel of an analog-to-digital converter computer system (C-lab, Indec Systems, Sunnyvale, CA). The signals from 2 photodiodes, each placed in a small portion of the light beam directed to the monochromators, were fed into 2 additional channels of the analog-to-digital converter.

The photomultiplier output was sorted into signal from 340 and 380 $\mathrm{nm}$ excitation by using the photodiode output as synchronizing signals. In the typical traces described here, 30 ratios were determined per second, the average ratio was displayed on-line, and the average intensity values for each wavelength were stored. After completion of a given experiment, the microscope stage was adjusted so that no cells or debris occupied the field of view defined by the diaphragm, and then background light levels were determined. Background light levels ranged from less than $5 \%$ for large cell bodies to close to $50 \%$ for very fine processes. Autofluorescence from cells that had not been loaded with fura-2 was not detectable. Records were later corrected for background and the ratios recalculated. Ratios were converted to free $\left[\mathrm{Ca}^{2+}\right]$ by using the equation $\left[\mathrm{Ca}^{2+}\right]=K\left(R-R_{\min }\right) /\left(R_{\max }-R\right)$, in which $R$ is the $340 / 380$ $\mathrm{nm}$ fluorescence ratio (Grynkiewicz et al., 1985). The maximum ratio $\left(R_{\text {mas }}\right)$, the minimum ratio $\left(R_{\min }\right)$, and the constant $K(K$ is the product of the dissociation constant for fura- 2 and the ratio of the free and bound forms of the dye at $380 \mathrm{~nm}$ ) were determined from a standard curve to which the above equation was fit using a nonlinear least-squares fit computer program. The system was recalibrated following any adjustment in the apparatus. Values for the constants $R_{\min }, R_{\max }$, and $K$ ranged from 0.121 to $0.334,4.02$ to 5.06 , and 2034 to 2373 , respectively. The standard curve was determined from the fura- 2 pentapotassium salt in calibration buffer (which contains, in mM, HEPES, 20; KCl, 120; $\mathrm{NaCl}, 5 ; \mathrm{pH} 7.1$ ) containing $10 \mathrm{mM} \mathrm{EGTA}, K_{\mathrm{s}}=3.969 \times 106 \mathrm{M}$ (Fabiato and Fabiato, 1979), and varying amounts of added $\mathrm{Ca}^{2+}$, which were calculated to give free $\mathrm{Ca}^{2+}$ concentrations ranging from 0 to $2000 \mathrm{nM}$. Records were digitally filtered with an algorithm that added $1 / 2$ the value of each data point with $1 / 4$ of the value of each of the 2 neighboring points. The data were cycled through this routine 5 times. Results are presented as means \pm SEM.

All experiments were performed on cells continuously perfused with HEPES Hank's solution. Depolarization-induced $\mathrm{CA}^{2+}$ influx was produced by changing the perfusing solution from low $\mathrm{K}^{+}(5 \mathrm{~mm})$ to high $\mathrm{K}^{+}(50 \mathrm{mM})$ with $\mathrm{K}^{+}$exchanged for $\mathrm{Na}^{+}$reciprocally. $\mathrm{Ca}^{2+}$-free solutions were prepared by replacing $\mathrm{Ca}^{2+}$ with $20 \mu \mathrm{M}$ EGTA.

Lipid metabolism. DRG cultures were incubated with either ${ }^{3} \mathrm{H}-\mathrm{myo}-$ inositol $(5 \mu \mathrm{Ci} / \mathrm{ml})$ for $48 \mathrm{hr}$ or ${ }^{3} \mathrm{H}$-arachidonic acid $(1 \mu \mathrm{Ci} / \mathrm{ml})$ for 10 $\mathrm{hr}$ in normal growth medium. In some experiments, cells were also incubated with 100-350 ng/ml pertussis toxin for $24 \mathrm{hr}$. Unincorporated isotope was removed by washing cultures 2 times with $2.4 \mathrm{ml}$ of HEPESbuffered Eagle's MEM containing $0.5 \mathrm{mg} / \mathrm{ml}$ fatty acid-free BSA. Cells were then incubated for $30 \mathrm{~min}$ in $2.5 \mathrm{ml} \mathrm{HEPES}$ Eagle's MEM at $37^{\circ} \mathrm{C}$. A final wash was performed, and the experiment was initiated after 5 min by the addition of BK ( $100 \mathrm{nM}$ except as indicated). The reaction was terminated after various intervals by rapid aspiration of the buffer and addition of either $2 \mathrm{ml}$ of $10 \%$ trichloroacetic acid (TCA) or $2 \mathrm{ml}$ of methanol for ${ }^{3} \mathrm{H}$-myoinositol- or ${ }^{3} \mathrm{H}$-arachidonic acid-labeled cells, respectively. In experiments in which arachidonic acid release was studied, the aspirated medium was saved. Cells were then scraped off the plate and added to $15 \mathrm{ml}$ glass centrifuge tubes. The TCA extracts were spun at $1000 \mathrm{rpm}$ for $5 \mathrm{~min}$. The supernatant was saved for inositol phosphate analysis and the pellet for phospholipid analysis. Chloroform, $2 \mathrm{ml}$, and $\mathrm{HCl}, 100 \mu \mathrm{l}$, were added to the methanol extracts and phaseseparated by the addition of $1.2 \mathrm{ml}$ of $1 \mathrm{~N} \mathrm{HCl} / 5 \mathrm{~mm}$ EGTA. The aqueous phase was removed, and the organic phase evaporated under $\mathrm{N}_{2}$ and saved for DAG analysis.

Analysis of inositol sugars. ${ }^{3} \mathrm{H}$-labeled inositol sugars were assayed by the method of Berridge et al. (1982). Briefly, TCA extracts containing the inositol sugars were extracted 5 times in an equal volume of ether to remove the acid and then neutralized with $50 \mathrm{~mm}$ tetraborate. The water-soluble inositol phosphates were then separated by ion-exchange chromatography on Dower- 1 X 8 (formate form). The samples were applied to $1 \mathrm{ml}$ columns of Dowex, and free inositol was washed through the columns with ten $2 \mathrm{ml}$ rinses of glass-distilled water. Subsequent elution of glycerol phosphoinositol, inositol monophosphate (IP), inositol bisphosphate $\left(\mathrm{IP}_{2}\right)$, and $\mathrm{IP}_{3}$ was accomplished by five $2 \mathrm{ml}$ rinses with the following buffers: $60 \mathrm{~mm}$ sodium formate $/ 5 \mathrm{~mm}$ sodium tetraborate; $0.1 \mathrm{M}$ formic acid/ $0.2 \mathrm{~m}$ ammonium formate; $0.1 \mathrm{M}$ formic acid/ $0.5 \mathrm{~m}$ ammonium formate; and $0.1 \mathrm{~m}$ formic acid $/ 1.0 \mathrm{~m}$ ammonium formate.

Phospholipid analysis. TCA pellets were resuspended in $1.5 \mathrm{ml}$ of chloroform/methanol/HCl $(100: 100: 1, \mathrm{vol} / \mathrm{vol})$, sonicated, and spun at $1000 \mathrm{rpm}$ for $5 \mathrm{~min}$. The supernatant was saved and the pellet extracted twice more in a similar manner first with $1.5 \mathrm{ml}$ of chloroform/methanol/ $\mathrm{HCl}(100: 100: 1)$ and then with $1 \mathrm{ml}$ of chloroform $/$ methanol/ $\mathrm{HCl}$ (200:100:1). The supernatants were pooled and phase-separated by the addition of $1.5 \mathrm{ml}$ chloroform and $1.5 \mathrm{ml} 0.1 \mathrm{M} \mathrm{HCl}$. The aqueous phase was removed and the organic phase washed twice with the theoretical upper phase [chloroform/methanol/water $(3: 48: 47)$ ] before drying under $\mathrm{N}_{2}$. After evaporation the residues were redissolved in $50 \mathrm{ml}$ of chloroform and applied to TLC plates (silica G). The phospholipids were separated on oxalate-impregnated silica plates and developed in chloroform, methanol, and $4 \mathrm{~N} \mathrm{NH}_{4} \mathrm{OH}$ (45:35:9.5) according to the method described by Billah and Lapetina (1982). Individual lipids were visualized by exposure to $I_{2}$ vapors. Zones corresponding to lipid standards were scraped and assayed for radioactivity by liquid scintillation methods.

$D A G$ analysis. For ${ }^{3} \mathrm{H}$-arachidonic acid-labeled DAG determination, the dried-down lipids were redissolved in $1 \mathrm{ml}$ chloroform and applied to a $2 \mathrm{ml}$ silicic acid column. Neutral lipids were eluted from the column by a $10 \mathrm{ml}$ rinse with chloroform. After evaporation of the column eluate under $\mathrm{N}_{2}$, the residue was redissolved in $50 \mu \mathrm{l}$ of chloroform and applied to TLC plates. Separation of DAG was achieved by developing 
A

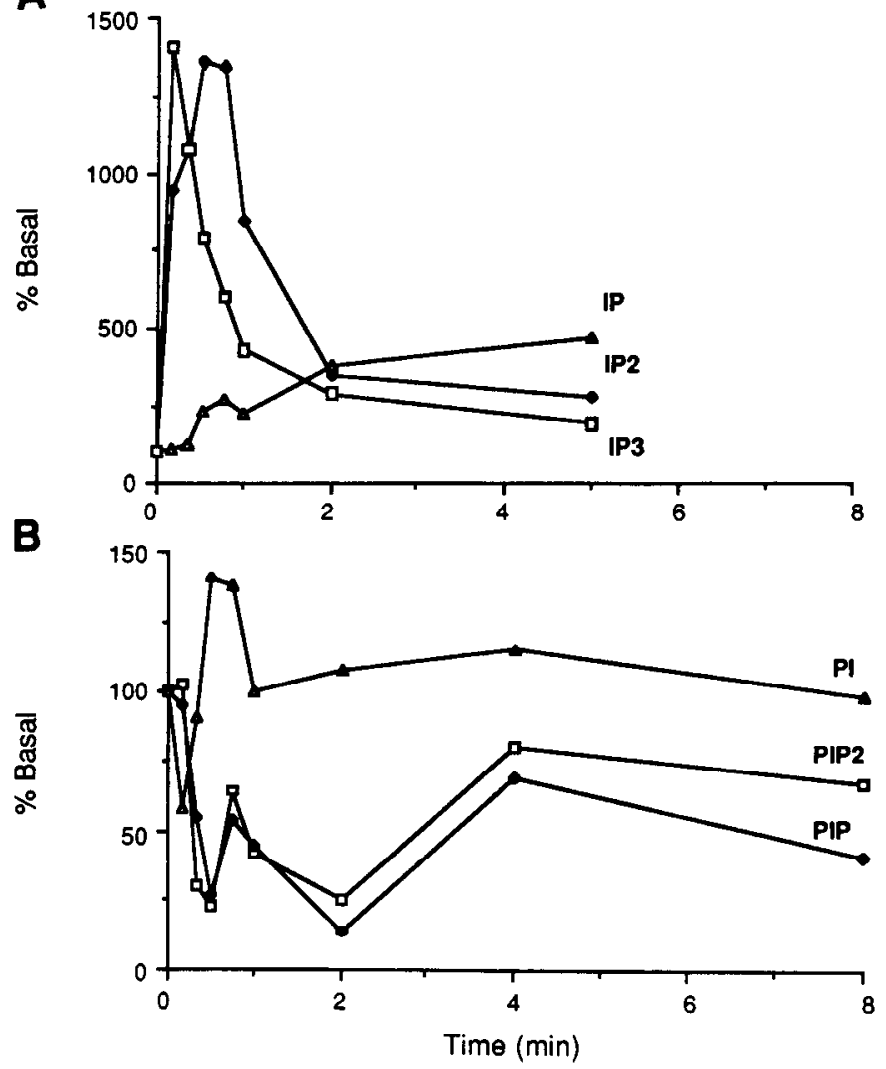

Figure 1. Time course of BK-stimulated phospholipid breakdown and inositol phosphate production. Cultured DRG neurons were prelabeled with ${ }^{3} \mathrm{H}$-myoinositol $(5 \mu \mathrm{Ci} / \mathrm{ml})$ for $48 \mathrm{~h}$ and then exposed to $\mathrm{BK}(100$ nM) for various intervals (see Materials and Methods) $A$, Inositol phosphate production. The data are expressed as percentage of the basal value. Each point represents the mean of duplicate determinations. This time course is representative of 3 experiments. The basal levels were ${ }^{3} \mathrm{H}-\mathrm{IP}{ }_{3}, 488 \mathrm{cpm} /$ plate; ${ }^{3} \mathrm{H}-\mathrm{IP}_{2}, 532 \mathrm{cpm} /$ plate; and IP, $2448 \mathrm{cpm} /$ plate. $B$, Phospholipid breakdown. The data are the mean of duplicate determinations and are expressed as percentage of the basal levels. Basal levels were $\mathrm{PIP}_{2}, 8.83 \times 10^{3} \mathrm{cpm} /$ plate; PIP, $8.75 \times 10^{3} \mathrm{cpm} / \mathrm{plate}$; and PI, $1.6 \times 10^{5} \mathrm{cpm} /$ plate.

the plates in ether/hexane/acetic acid (70:30:1) as described by Griendling et al. (1986).

Arachidonic acid release. The release of ${ }^{3} \mathrm{H}$-arachidonic acid and its metabolites into the medium was determined by assaying $200 \mathrm{ml}$ aliquots of the medium for radioactivity by liquid scintillation spectrophotometry. In some experiments, ${ }^{3} \mathrm{H}$-arachidonic acid in the organic phase was separated from its metabolites by TLC [developed in chloroform/isopropanol/ethanol/formic acid (45:5:0.5:0.3)] after extraction of the medium in $6 \mathrm{ml}$ chloroform/methanol $(2: 1)$. The 2 methods yielded similar results.

\section{Results}

\section{Phospholipid metabolism}

In many cell types, BK has been shown to activate both phospholipase $C$ and phospholipase $A_{2}$ (Miller, 1987b). For example, this has been demonstrated in some neuronal clonal cell lines, although not in authentic DRG cells (Yano et al., 1984; Francel and Dawson, 1986; Francel et al., 1987; Jackson et al., 1987; Van Calker and Heumann, 1987). We therefore began by examining the effects of BK on phospholipid metabolism in cultures of rat DRG neurons in vitro. $\mathrm{BK}$, in the range $10^{-9}-10^{-6}$ $M$, rapidly stimulated the production of $I P, I_{2}$, and $I P_{3}$ (Figs.

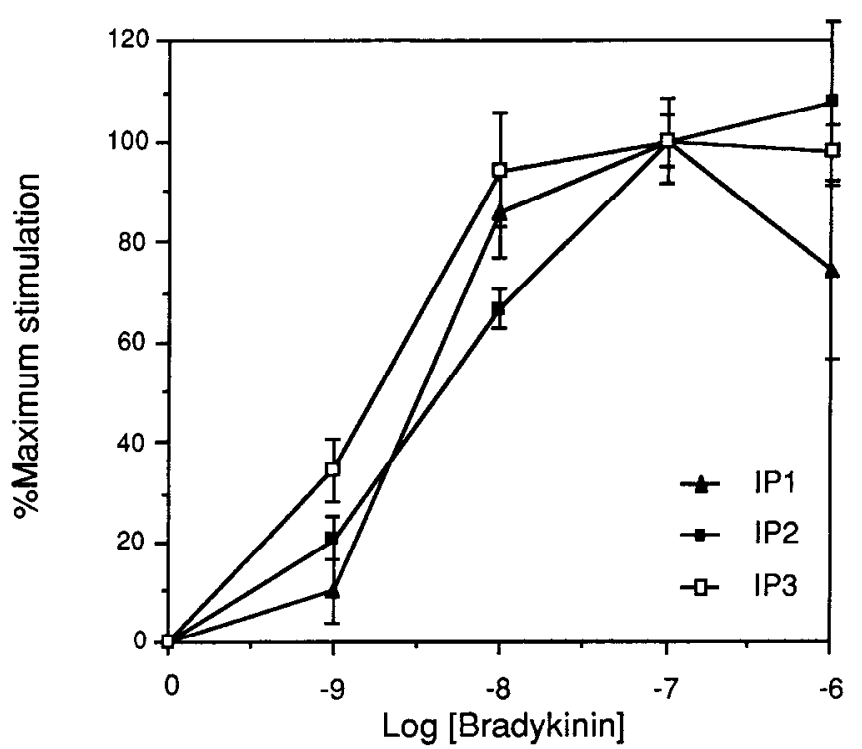

Figure 2. Dose dependence of BK-stimulated inositol phosphate production. Cultured DRG neurons were prelabeled with ${ }^{3} \mathrm{H}$-myoinositol $(5 \mu \mathrm{Ci} / \mathrm{ml})$ for $48 \mathrm{hr}$ and then exposed to $\mathrm{BK}$ at various concentrations for $30 \mathrm{sec}$ (see Materials and Methods). Data are means \pm SE of triplicate determinations and are expressed as percentage of the control value.

1 and 2). The synthesis of $\mathrm{IP}_{3}$ was seen most rapidly followed by that of $\mathrm{IP}_{2}$ and then IP. Large increases in the synthesis of $\mathrm{IP}_{3}$ were observed (up to 20 -fold). As reported for a variety of other systems, the agonist stimulated synthesis of $\mathrm{IP}_{3}$ and $\mathrm{IP}_{2}$ was relatively transient, declining to basal levels over a few minutes. In contrast, the slower and less profound synthesis of IP was more sustained and was still apparent at the termination of experiments ( $5 \mathrm{~min}$ ). As would be expected during the period over which the synthesis of $\mathrm{IP}_{3}$ and $\mathrm{IP}_{2}$ occurred, the concentrations of $\mathrm{PIP}_{2}$ and PIP fell (Fig. 1). BK-stimulated $\mathrm{IP}_{3}$ production was not blocked after pretreatment of cells with pertussis toxin (PTX) (Fig. 3). BK also increased the production of DAG by DRG cells (Fig. 4). Interestingly, the time course of DAG production was considerably longer than that observed for $\mathrm{IP}_{3}$. An initial peak of DAG production occurred that correlated in time with the production of $\mathrm{IP}_{3}$. However, this was followed by a second extended peak of DAG production that lasted for many minutes. Such biphasic agonist-induced DAG production has now been noted in many cases and may reflect multiplc sources of DAG (Miller, 1988). These observations make it clear that BK does activate phospholipase $C$ in DRG neurons. We also found that $B K$ activated phospholipase $A_{2}$. BK stimulated the release of ${ }^{3} \mathrm{H}$-arachidonic acid and its metabolites from labeled DRG cells. In the presence of $\mathrm{BK}\left(10^{-7} \mathrm{M}\right)$, the levels of radioactivity released into the culture medium rose to $115.8 \pm 7.9 \%$ of control after $30 \mathrm{sec}$ and $127.4 \pm 8.5 \%$ of control after $5 \mathrm{~min}$ of incubation $(n=18)$. This release was not significantly reduced by pertussis toxin treatment $(n=10)$. In one experiment, we also observed that $\mathrm{BK}\left(10^{-7} \mathrm{M}\right)$ stimulated the production of lyso-PI by the cells.

\section{Intracellular $\mathrm{Ca}^{2+}$ stores}

$\mathrm{IP}_{3}$ has been shown to mobilize $\mathrm{Ca}^{2+}$ from intracellular stores in a number of cell types (Berridge, 1987). We therefore examined the effects of $\mathrm{BK}$ on $\left[\mathrm{Ca}^{2+}\right]$ in different portions of rat DRG neurons and compared it with the effects of other stimuli 
Figure 3. Effects of pertussis toxin on BK-stimulated inositol phosphate production. Cultured DRG neurons were prelabeled with ${ }^{3} \mathrm{H}$-myoinositol $(5 \mu \mathrm{Ci} /$ $\mathrm{ml})$ and then exposed to $\mathrm{BK}(100 \mathrm{nM})$ for $30 \mathrm{sec}$. For some of the cultures, 350 $\mathrm{ng} / \mathrm{ml}$ pertussis toxin was added $24 \mathrm{hr}$ after labeling had begun. Data are means \pm SE of triplicate determinations in 4 experiments and are expressed as perterials and Methods). A similar experiment in which the time of exposure to $\mathrm{BK}$ was varied also showed no pertussis toxin sensitivity to the response. centage of the control value (see Ma-

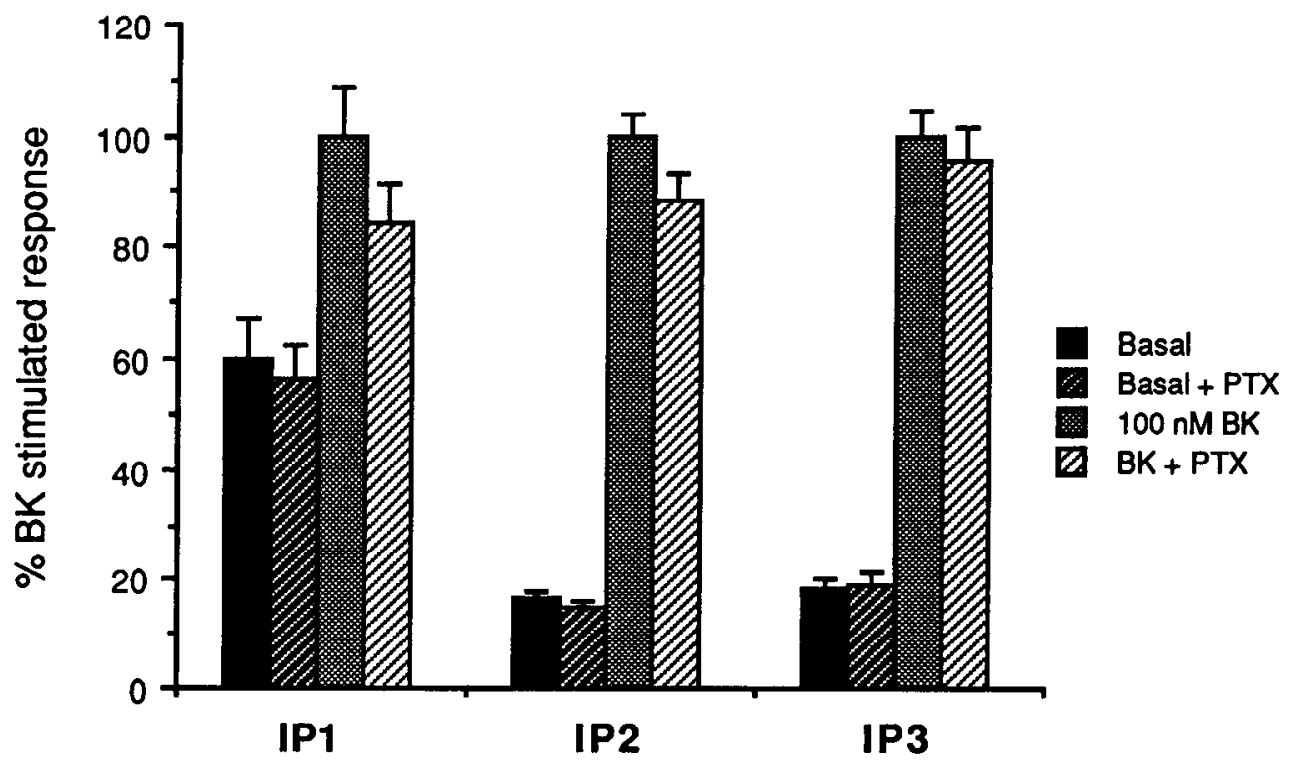

that affect $\left[\mathrm{Ca}^{2+}\right]_{i}$. In the cell bodies of DRG cells, depolarization induced by raising $\left[\mathrm{K}^{+}\right]_{0}$ induced a rapid rise in $\left[\mathrm{Ca}^{2+}\right]^{2}$. This occurred in $100 \%$ of the cells examined (Figs. 5,9$).\left[\mathrm{Ca}^{2+}\right]_{\mathrm{i}}$ rose from a resting concentration of $77 \pm 7 \mathrm{nM}(n=30)$ to $513 \pm$ $6 \mathrm{nM}(n=27)$ (Figs. 5, 9). In $\mathrm{Ca}^{2+}$-free medium, the response to depolarization was completely blocked (Fig. $5 \mathrm{~B}$ ). A striking feature of the depolarization-induced $\mathrm{Ca}^{2+}$ transient in DRG cells was that it was buffered very slowly. Following washout of the depolarizing stimulus, $\left[\mathrm{Ca}^{2}\right]_{i}$ initially fell rapidly but then stabilized and only declined very slowly even in $\mathrm{Ca}^{2+}$-free medium (Figs. 5, 6). This slow buffering of $\mathrm{Ca}^{2+}$ stands in contrast to other types of peripheral and central neurons we have examined, which buffer similar $\mathrm{Ca}^{2+}$ loads much more quickly (Fig. 6) (Murphy et al., 1987; Thayer et al. 1987a).

Methylxanthines such as caffeine have been shown to mobilize $\mathrm{Ca}^{2+}$ from intracellular stores in several types of cells, including peripheral neurons (Neering and McBurney, 1984; Lipscombe et al., 1987; Thayer et al., 1987b). Caffeine was also very effective in DRG cell bodies. In $\mathrm{Ca}^{2+}$-free medium, $10^{-2} \mathrm{M}$



Figure 4. Time course of bradykinin stimulated diacylglycerol formation. Cultured DRG neurons were prelabeled with $\left[{ }^{3} \mathrm{H}\right]$ arachidonic acid $(1 \mu \mathrm{Ci} / \mathrm{ml})$ for $10 \mathrm{hr}$ and then exposed to bradykinin $(100 \mathrm{~nm})$ for various intervals. This time course is representative of three similar experiments. (See Materials and Methods).
A

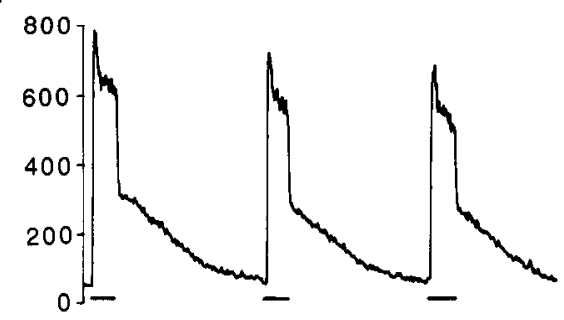

B
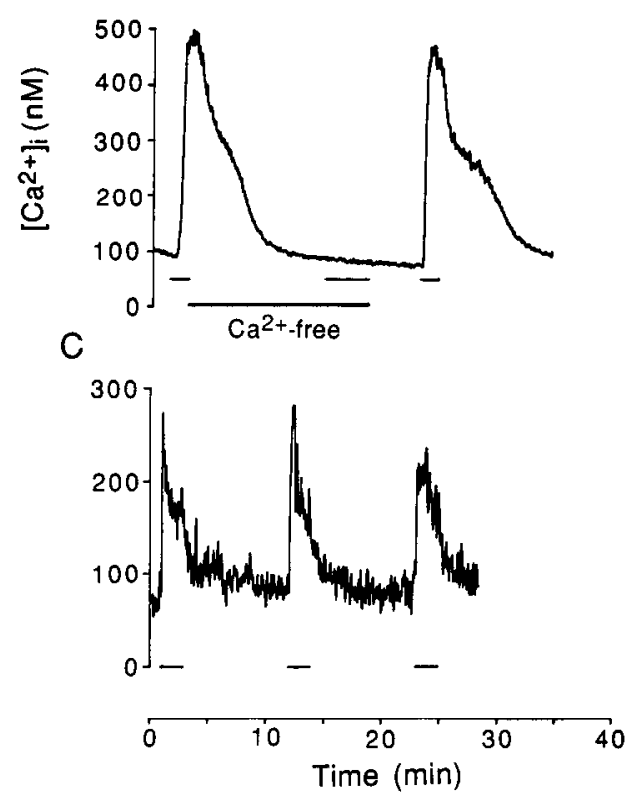

Figure 5. Depolarization-induced increases in $\left[\mathrm{Ca}^{2+}\right]_{\mathrm{i}}$ in sensory neurons. $\left[\mathrm{Ca}^{2+}\right]_{i}$ was measured in single DRG cell bodies $(A$ and $B)$ and processes $(C)$ as described in Matcrials and Methods. Cells were depolarized during the time indicated by the horizontal bars by changing the perfusing solution from low $(5 \mathrm{mM})$ to high $(50 \mathrm{mM}) \mathrm{K}^{+}$media. In contrast to the 3 control responses generated in $A$, depolarization in $\mathrm{Ca}^{2+}-$ free $(20 \mu \mathrm{M}$ EGTA) media (horizontal bar) failed to elicit a response $(B)$. Depolarization of a neuronal process $(C)$ produced $\left[\mathrm{Ca}^{2+}\right]_{\mathrm{i}}$ transients that were smaller and more rapidly buffered than those elicited in cell bodies. 


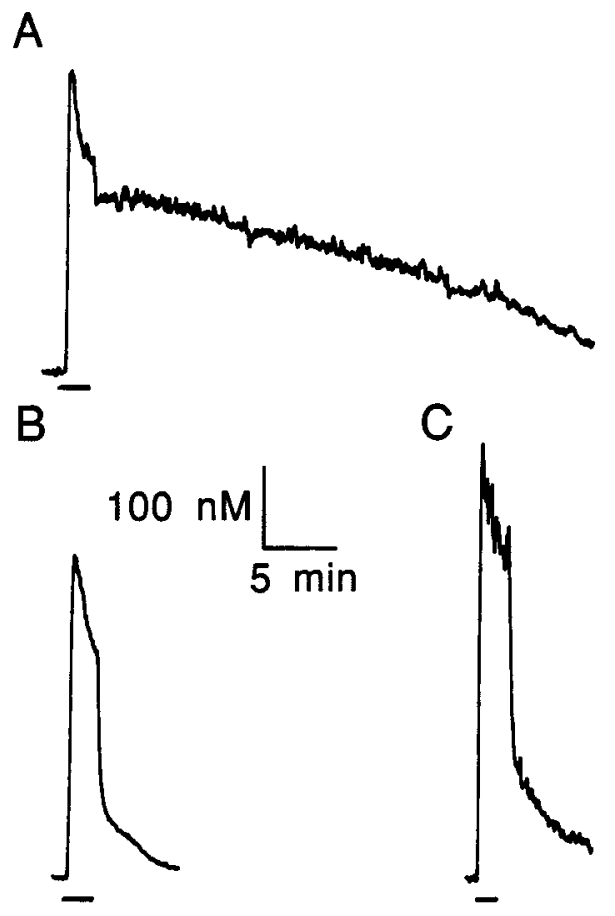

Figure 6. Comparison of $\mathrm{Ca}^{2+}$ buffering in sensory, sympathetic, and central ncurons. Single somata from the DRG $(A)$, the SCG $(B)$, and the striatum $(C)$ were depolarized during the time indicated by the horizontal bars by changing the perfusing solution from low $(5 \mathrm{~mm})$ to high $(50 \mathrm{~mm}) \mathrm{K}^{+}$media. $\left[\mathrm{Ca}^{2+}\right]_{\mathrm{i}}$ was measured as described in Materials and Methods.

caffeine produced $\mathrm{Ca}^{2+}$ transients in the vast majority of cells examined (83\%, Figs. 7,9$)$. In order to elicit multiple responses to caffeine, the stores required "refilling" after each exposure. This could be achieved by depolarizing the cell briefly in $\mathrm{Ca}^{2+}-$ containing medium and allowing $\mathrm{Ca}^{2+}$ influx to elevate $\left[\mathrm{Ca}^{2+}\right]_{\mathrm{i}}$ (Fig. 7). The caffeine-sensitive stores in DRG neurons seem to be similar to those seen in muscle cells, as the caffeine-induced increases in $\left[\mathrm{Ca}^{2+}\right]_{i}$ could be completely blocked by ryanodine (Fig. 7). The block produced by ryanodine was "use dependent." Thus, after addition of ryanodine, a caffeine response could be obtained initially; however, after this first response, all subsequent attempts to elicit a caffeine response, even after normal "refilling," were completely blocked. We have observed that the ryanodine block of the caffeine response had precisely the same characteristics in rat sympathetic neurons (Thayer et al., 1987b). BK also produced $\mathrm{Ca}^{2+}$ transients in DRG cell bodies. These were still observed in $\mathrm{Ca}^{2+}$-free medium. The magnitude of the $\mathrm{Ca}^{2+}$ transients produced by BK were similar to those produced by caffeine, although they were observed in considerably fewer cells (33\%; Figs. 8, 9). The effects produced by BK desensitized. Following the production of a BK response, subsequent applications of the peptide produced progressively smaller responses even if attempts were made to refill stores as with caffeine (Fig. 8).

The effects of these various stimuli on $\left[\mathrm{Ca}^{2+}\right]_{\mathrm{i}}$ in individual DRG cell processes were also examined. Several interesting differences were observed in comparison with results obtained in cell bodies. First, we found that elevating $\left[\mathrm{K}^{+}\right]_{0}$ was less effective in raising $\left[\mathrm{Ca}^{2+}\right]_{i}$ in cell processes (Figs. 5, 9). Although this depolarizing stimulus was still effective in every process examined, the net rise in $\left[\mathrm{Ca}^{2+}\right]_{\mathrm{i}}$ to $219 \pm 37 \mathrm{nM}(n=23)$ was

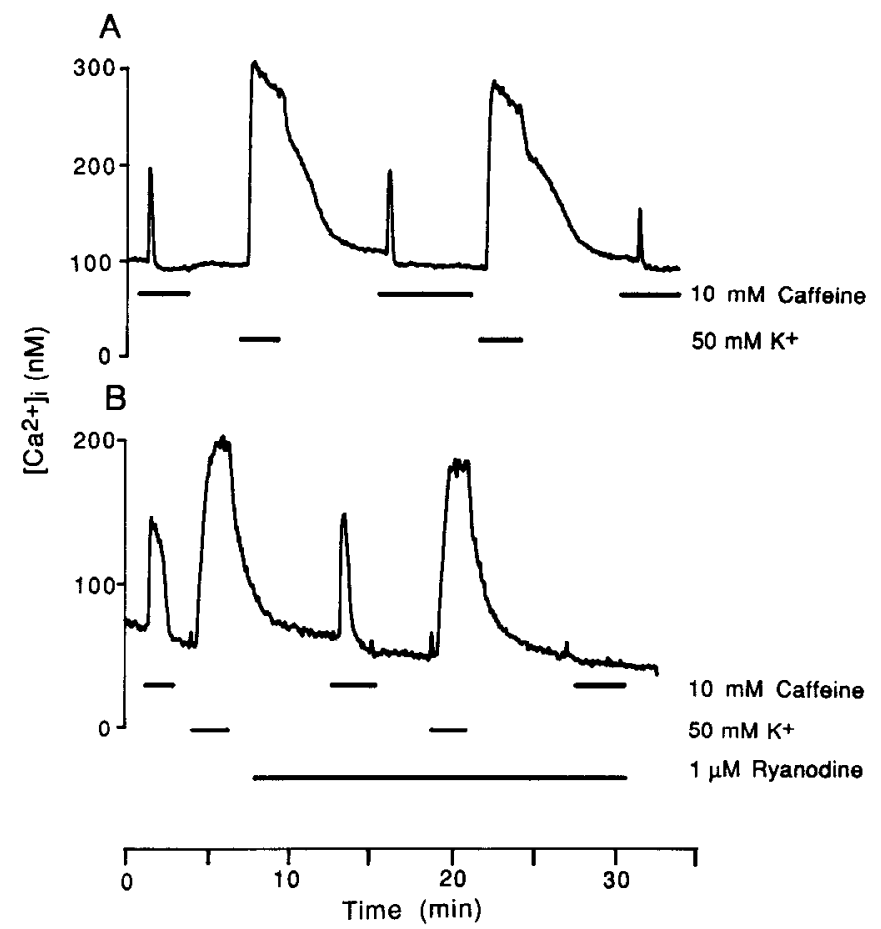

Figure 7. Caffeine-sensitive $\mathrm{Ca}^{2+}$ stores in sensory neurons. In DRG neurons perfused with $\mathrm{Ca}^{2+}$-free ( $20 \mu \mathrm{M}$ EGTA) medium, adding $10 \mathrm{~mm}$ caffeine to the solution at the times indicated, produced a rapid and transient increase in $\left[\mathrm{Ca}^{2+}\right]_{i}$. Multiple responses to caffeine could be elicited only if the intracellular stores were allowed to refill with $\mathrm{Ca}^{2+}$, accomplished here by perfusing with depolarizing ( $50 \mathrm{~mm} \mathrm{~K} \mathrm{~K}^{+}$) media containing normal $\mathrm{Ca}^{2+}$ levels. When $1 \mu \mathrm{M}$ ryanodine was added to the perfusing medium prior to and during the second application of caffeine $(B)$, the response to the third application of caffeine was always blocked. $\left[\mathrm{Ca}^{2+}\right]_{i}$ was measurcd as described in Matcrials and Methods.

considerably smaller than that observed in the soma (Figs. 5, 9). This is in contrast to sympathetic neurons, for example, in which we observed that raising $\left[\mathrm{K}^{+}\right]_{0}$ increased $\left[\mathrm{Ca}^{2+}\right]_{i}$ in cell bodies and processes to a similar extent (Thayer et al., 1987a). The observations on DRG cells suggest some variability in the density of $\mathrm{Ca}^{2+}$ channels in different parts of the cell. In addition, increases in $\left[\mathrm{Ca}^{2+}\right]_{i}$ produced by depolarization in cell processes were much more transient than the long-lasting increases observed in cell bodies (Fig. 5). Striking differences were also observed with respect to the effects of caffeine in cell processes. Whereas caffeine was very effective in virtually all cell bodies tested, it rarely produced any effects in cell processes. We did observe occasional small responses to caffeine in processes, but they were very infrequent (Fig. 9). These observations are similar to others made in rat and bullfrog sympathetic neurons, in which the effects of caffeine on $\left[\mathrm{Ca}^{2+}\right]_{\mathrm{i}}$ are also restricted to the cell soma (Lipscombe, 1987; Thayer et al., 1987a) (Figs. 9, 10). In contrast to caffeine, BK was at least as effective in cell processes as in the cell soma. The average increases in $\left[\mathrm{Ca}^{2+}\right]_{\mathrm{i}}$ produced by $\mathrm{BK}$ in cell processes $(126 \pm 57 \mathrm{nM}, n=10)$ were similar to those observed in cell bodies $(108 \pm 37 \mathrm{nM}, n=10)$, and the response was seen more frequently ( 43 versus $33 \%$; Fig. 9). These differential effects could indicate that the stores activated by caffeine and BK are different. That this may be so is further suggested by results such as those shown in Figure 10. There, we illustrate a cell body that failed to respond to BK but showed a large caffeine reponse. In contrast, a DRG process in 
Figure 8. BK-induced increases in $\left[\mathrm{Ca}^{2+}\right]_{i}$. The cell body of a sensory neuron was perfused with either $100 \mathrm{nM} B \mathrm{BK}$ or depolarizing $\left(50 \mathrm{mM} \mathrm{K} \mathrm{K}^{+}\right.$) medium at the times indicated by the horizontal hars. $\left[\mathrm{Ca}^{2+}\right]_{\text {in }}$ was measured as described in Materials and Methods.



which caffeine failed to elicit a response showed a large BK effect. Such differential sensitivity was frequently observed. Although lack of a response to BK may indicate the absence of BK receptors in some instances, taken together these results strongly suggest that caffeine and $\mathrm{BK}\left(\mathrm{IP}_{3}\right.$ ?)-sensitive stores are separate entities.
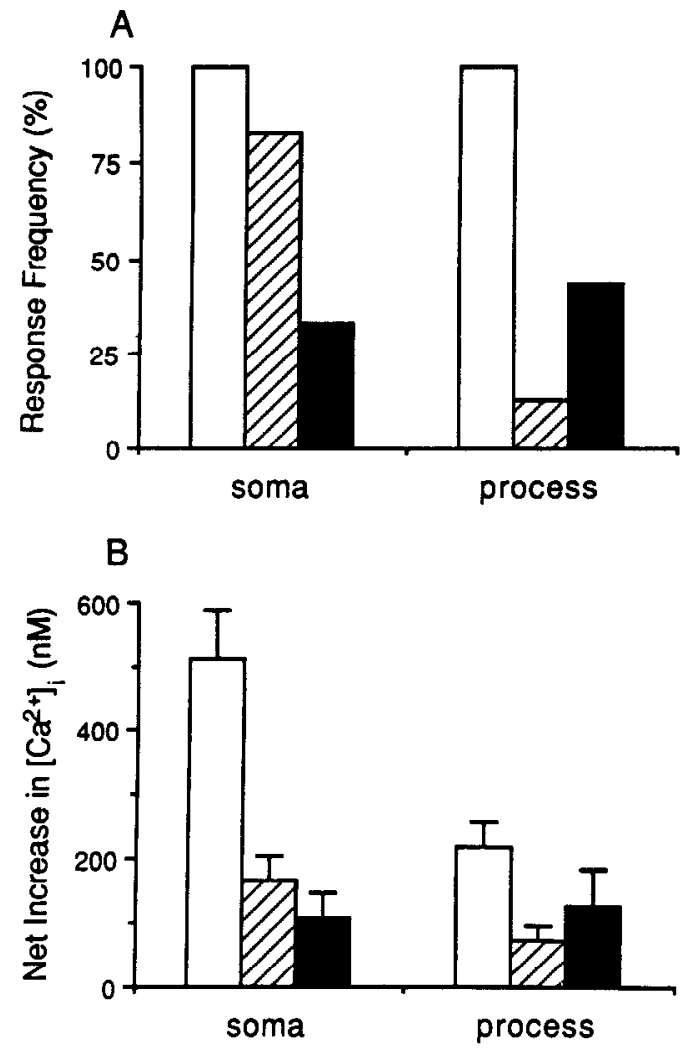

Figure 9. Comparison of the increases in $\left[\mathrm{Ca}^{2+}\right]_{\mathrm{i}}$ produced by depolarization, caffeine, and BK in somata and processes of sensory neurons. The frequency $(A)$ and magnitude $(B)$ of the responses in either DRG somata or processes to perfusion with media containing $50 \mathrm{mM} \mathrm{K}^{+}$(open bars), $10 \mathrm{~mm}$ caffeine (hatched bars), or $100 \mathrm{nM}$ BK (solid bars) are shown. Basal $\left[\mathrm{Ca}^{2+}\right]_{\mathrm{i}}$ levels were subtracted from the peak responses and displayed as means $\pm \mathrm{SE}$.
Another observation we have made concerns the potential role of intracellular $\mathrm{Ca}^{2+}$ storage sites in $\mathrm{Ca}^{2+}$ buffering. As discussed above, the shape of the $\mathrm{Ca}^{2+}$ transient evoked by depolarization in the cell bodies of DRG neurons is very characteristic. After a rapid initial decline, the $\mathrm{Ca}^{2+}$ signal decays only very slowly. We found, however, that the shape of this transient could be radically altered if either caffeine- or BKsensitive stores were first discharged. After such treatment, the long-lasting tail of the $\mathrm{Ca}^{2+}$ transient was abolished or at least very greatly reduced (Fig. 11). Following washout of the caffeine or BK stimulus, the depolarization-evoked $\mathrm{Ca}^{2+}$ transients returned to their original form. Indeed, following discharge of intracellular stores, the $\mathrm{Ca}^{2+}$ transients obtained by depolarization of DRG cells resembled those obtained in other peripheral or central neurons (see above). We also observed that acute treatment of cells with phorbol esters or down-regulation of protein kinase $\mathrm{C}$ following chronic phorbol ester treatment (Matthies et al., 1987; Ewald et al., 1988) did not alter the buffering of $\mathrm{Ca}^{2+}$ by the cells. This indicates that the effects of $\mathrm{BK}$ on $\mathrm{Ca}^{2+}$ buffering do not involve protein kinase $\mathrm{C}$ but are presumably related to the discharge of $\mathrm{IP}_{3}$-sensitive stores.

We have noted above that the activation of $\mathrm{IP}_{3}$ synthesis produced by BK in DRG neurons was not blocked by pertussis toxin. We therefore examined the effect of the toxin on BKinduced $\mathrm{Ca}^{2+}$ transients in cell processes. Quite surprisingly, we observed that, although BK was still effective in some instances, its ability to increase $\left[\mathrm{Ca}^{2+}\right]_{\mathrm{i}}$ in pertussis toxin-treated cells seemed to be substantially decreased (13\% of the processes responded after treatment, $n=19$ with a mean response of $60 \pm 24 \mathrm{nM}$; $n=3$ ). Caffeine, as noted, produced very little effect in cell processes; if anything, however, it was even less effective following the toxin ( $11 \%$ responded, $n=19$; mean $37 \mathrm{nM} ; n=2$ ). In contrast, pertussis toxin had no effect upon the size of the $\mathrm{Ca}^{2+}$ transients produced in cell processes by depolarization (net increase $261 \pm 47 \mathrm{nM}, n=19$ ).

\section{Discussion}

The action of BK on virtually all its target cells leads to the activation of both phospholipase $\mathrm{C}$ and phospholipase $\mathrm{A}_{2}$. This, in turn, leads to the production of a variety of lipid-derived 


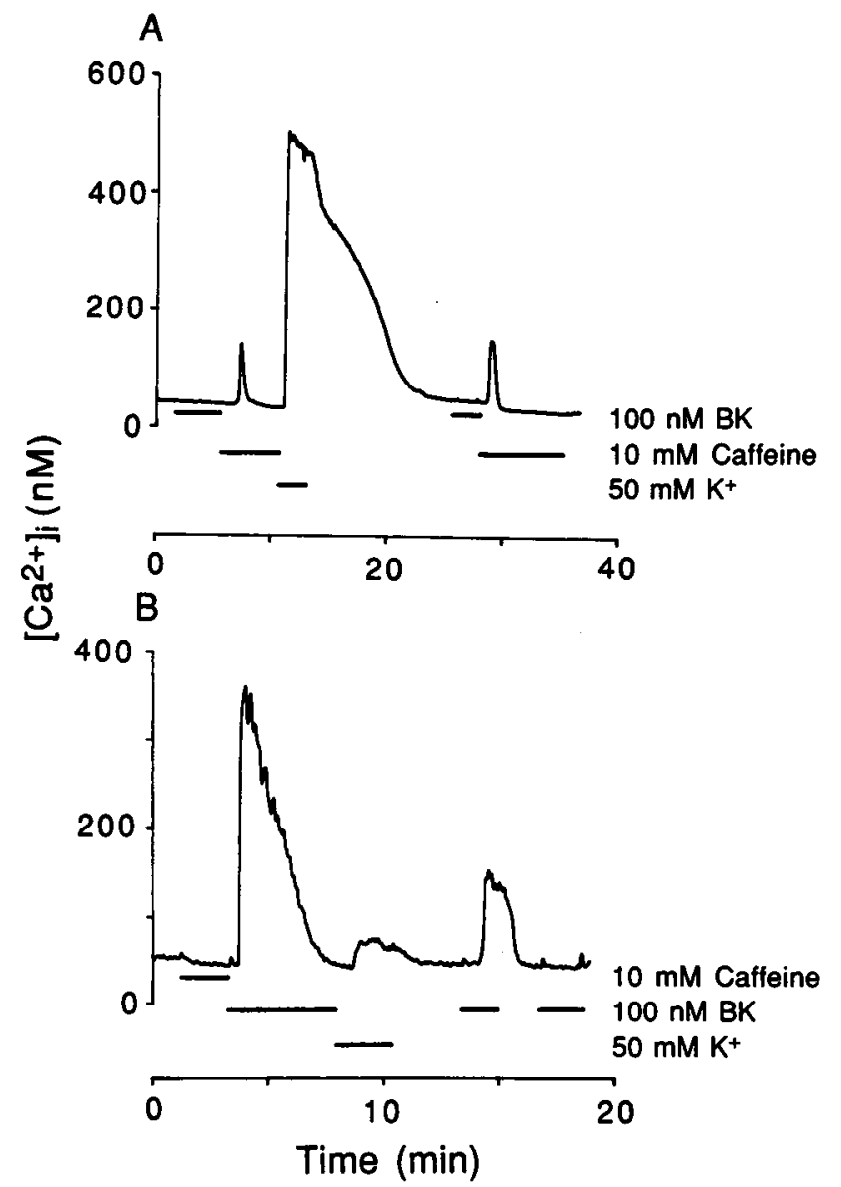

Figure 10. Separation of $\mathrm{BK}$ and caffeine sensitivity of the intracellular $\mathrm{Ca}^{2+}$ stores in sensory neurons. A DRG soma $(A)$ and process $(B)$ were perfused with $\mathrm{Ca}^{2+}$-free ( $20 \mu \mathrm{M}$ EGTA) solution containing either 100 nM BK or $10 \mathrm{~mm}$ caffeine as indicated. Depolarization-induced $\mathrm{Ca}^{2+}$ influx was produced by perfusion with $50 \mathrm{~mm} \mathrm{~K} \mathrm{~K}^{+}$in normal $\mathrm{Ca}^{2+}$ containing medium. The BK response in the process $(B)$ is an especially large $\left[\mathrm{Ca}^{2+}\right]_{i}$ transient chosen because of the low noise in the record.

second messengers (Hong and Deykin, 1982; Miller, 1987b). Such substances could mediate the known effects of BK on DRG excitability (Miller, 1987b). In the present study we have demonstrated that in DRG cells, as in other cases, BK does indeed stimulate the production of several phospholipid-derived second messengers, suggesting that it activates phospholipases $\mathrm{C}$ and $\mathrm{A}_{2}$. As in other cases, the $\mathrm{IP}_{3}$ produced probably plays an important role in mediating the $\mathrm{BK}$-induced changes in $\mathrm{Ca}^{2+}$ metabolism we have observed. The role of arachidonic acid in this respect is unclear, and we have not investigated it further. However, as we shall discuss, DAG and eicosanoids derived from the metabolism of arachidonic acid are clearly essential in producing the overall excitatory effects of BK on DRG cells. This is primarily due to their effects on $\mathrm{Ca}^{2+}$ and $\mathrm{K}^{+}$conductances (see below).

The general pattern of phospholipid metabolism produced by BK in DRG cells is similar to that previously reported in other tissues including a DRG $\times$ neuroblastoma clonal cell line, F11 (Francel et al., 1987). One difference concerns the effects of PTX. In DRG cells, PTX had no effect on $\mathrm{IP}_{3}$ production. However, in F-1 1 cells a partial inhibitory effect was observed (Francel et al., 1987). Although it is clear that agonist-induced $\mathrm{IP}_{3}$ synthesis utilizes a G-protein of some sort, the PTX sensitivity of this

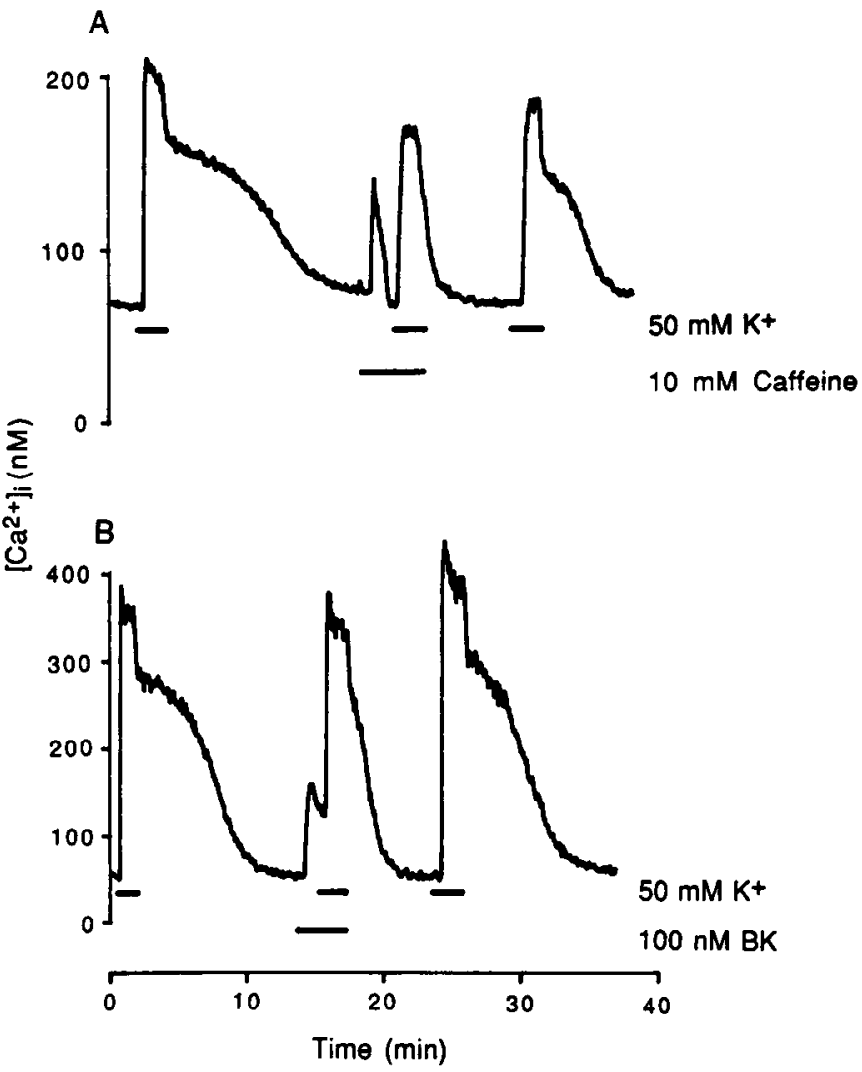

Figure 11. Intracellular stores and $\left[\mathrm{Ca}^{2+}\right]$ buffering in sensory neurons. Increases in the $\left[\mathrm{Ca}^{2+}\right]_{i}$ in DRG cell bodies were induced by perfusion with depolarizing ( $50 \mathrm{~mm} \mathrm{~K}$ ) medium in normal $\mathrm{Ca}^{2+}$ as indicated by the horizontal bars. The cells were perfused with $\mathrm{Ca}^{2+}$-free $(20 \mu \mathrm{M}$ EGTA) solution during the recovery to basal $\left[\mathrm{Ca}^{2+}\right]_{\mathrm{i}}$ levels. Caffeine, $10 \mathrm{mM}(A)$, or $\mathrm{BK}, 100 \mathrm{nM}(B)$, was added to the perfusion solution prior to and during the depolarization as indicated by the horizontal bars.

entity (or entities) has been found to vary widely (Miller, 1988). Actually, it is only in a minority of cases that PTX sensitivity of the IP ${ }_{3}$ generating process has been observed (Berridge, 1987; Miller, 1988). In the particular case of BK, both PTX-sensitive and -insensitive $\mathrm{IP}_{3}$ production has been reported (Miller, 1988). Whether this means that BK receptors can be coupled to different G-proteins (Burch and Axelrod, 1987) or whether it reflects the known heterogeneity of BK receptors is as yet unclear (Manning et al., 1986).

In many cell types, $\mathrm{IP}_{3}$ generation subsequently leads to the mobilization of intracellular $\mathrm{Ca}^{2+}$ (Berridge, 1987). This also appears to be true in DRG cells. BK clearly produced increases in $\left[\mathrm{Ca}^{2+}\right]_{i}$ in many cells even in $\mathrm{Ca}^{2+}$-free medium. It is interesting to note that reponses to $\mathrm{BK}$ appeared to be of about the same magnitude even if $\mathrm{Ca}^{2+}$-containing medium was used ( $\mathrm{S}$. Thayer and R. Miller, unpublished observations). This indicates that $\mathrm{BK}$ does not produce extensive $\mathrm{Ca}^{2+}$ influx. Thus, any subsequent metabolism of $\mathrm{IP}_{3}$ to $\mathrm{IP}_{4}$ and associated $\mathrm{Ca}^{2+}$ influx in these neurons may not be of great importance (Higashida and Brown, 1986a; Irvine and Moore, 1986; Morris et al., 1987). It should be pointed out that, although we imagine that the increases in $\left[\mathrm{Ca}^{2+}\right]_{i}$ we have observed in response to $\mathrm{BK}$ involve $\mathrm{IP}_{3}$, the ability of $\mathrm{IP}_{3}$ to actually mobilize $\mathrm{Ca}^{2+}$ in DRG cells (or indeed in any other type of vertebrate neuron) remains to be directly demonstrated (see, however, Freedman and Aghanjanian, 1987; Shah et al., 1987). BK did not increase $\left[\mathrm{Ca}^{2+}\right]_{\mathrm{i}}$ in all 
neurons studied. This is probably a reflection of some degree of heterogeneity in the cultures. BK receptors probably exist primarily on small polymodal nociceptors and may not be present on the cell bodies or processes of all DRG neurons.

In our studies, it appeared that $\mathrm{BK}$-sensitive $\mathrm{Ca}^{2+}$ stores existed in both the cell soma and processes. These stores may differ from those that can be mobilized by high concentrations of methylxanthines. It is well known that caffeine can mobilize an intracellular $\mathrm{Ca}^{2+}$ store in various types of muscle (Carafoli, 1987). It is thought that this type of store can participate in the phenomenon of " $\mathrm{Ca}^{2+}$-induced $\mathrm{Ca}^{2+}$ release," which may be a way of amplifying the $\mathrm{Ca}^{2+}$ signal in these cells (Barcenas-Ruiz and Weir, 1987; Carafoli, 1987). By implication, such stores have also been thought to exist in bullfrog sympathetic neurons (Kuba, 1980), and this fact has now been directly demonstrated using imaging techniques (Lipscombe et al., 1987). Studies we have carried out using rat superior cervical ganglion neurons have also demonstrated the existence of caffeine-sensitive stores which can be blocked by both ryanodine and dantrolene (Thayer et al. 1987b). Presumably, therefore, these stores are similar to those found in muscle. The present studies demonstrate that methylxanthine-sensitive stores also seem to exist in DRG cells where again they can be blocked by ryanodine. It has been observed that in both rat and bullfrog sympathetic neurons caffeine-sensitive stores seem to exist primarily in the cell soma (Lipscombe et al., 1987; Thayer et al., 1987b). This is also true in DRG cells. We also noted that in many instances it was possible to produce BK responses from a cell process that was completely insensitive to caffeine. If we make the assumption that the $\mathrm{BK}$-induced rise in $\left[\mathrm{Ca}^{2+}\right]_{\mathrm{i}}$ results from $\mathrm{BK}$-stimulated $\mathrm{IP}_{3}$ synthesis and subsequent mobilization of $\mathrm{Ca}^{2+}$ stores, then it appears likely that the caffeine and $\mathrm{IP}_{3}$-sensitive stores are separate entities. Indeed, such a separation of $\mathrm{IP}_{3}$ - and caffeinesensitive stores has also been observed in non-neuronal tissues (Kanaide et al., 1987).

It is clear from our data that the manner in which DRG cells buffer $\mathrm{Ca}^{2+}$ is quite extraordinary. In comparison with all other types of peripheral and central neurons we have studied, the shape of the $\mathrm{Ca}^{2+}$ transient produced upon depolarization is remarkable. Following a rapid phase of buffering, $\left[\mathrm{Ca}^{2+}\right]_{i}$ falls very slowly. The tardiness of $\mathrm{Ca}^{2+}$ buffering in these cells is also observed on a much shorter time scale when voltage-clamp steps are used to depolarize the cells (Thayer et al., 1988). It is interesting to note that Jia and Nelson (1986) predicted that DRG cells might buffer $\mathrm{Ca}^{2+}$ slowly on the basis of the paucity of mitochondria they observed in DRG nerve terminals. However, it is not clear that this is actually the reason involved. Thus, the $\mathrm{Ca}^{2+}$ transients observed in cell processes seem considerably faster than those observed in the cell soma. Our results indicate that the rate of $\mathrm{Ca}^{2+}$ buffering may be critically dependent on the availability of intracellular $\mathrm{Ca}^{2+}$ storage sites. Thus, if we discharged either the $\mathrm{BK}$ - or caffeine-sensitive stores, $\mathrm{Ca}^{2+}$ buffering in the cell soma became relatively fast. This seems reasonable. $\mathrm{K}^{+}$depolarization, $\mathrm{BK}$, and caffcine all raise $\left[\mathrm{Ca}^{2+}\right]_{\mathrm{i}}$ into the submicromolar range but seldom higher. Thus, a relatively high-affinity $\mathrm{Ca}^{2+}$ buffer is probably most important for the rapid removal of the accumulated $\mathrm{Ca}^{2+}$. Mitochondria and exchange systems are generally of lower affinity than intracellular $\mathrm{Ca}^{2+}$ storage sites or the cell membrane $\mathrm{Ca}^{2+}$ ATPase (Baker and DiPolo, 1984; Carafoli, 1987). We presume that after loading during elevated $\mathrm{K}$ ' depolarization, the $\mathrm{Ca}^{2+}$ buffering that occurs rapidly mostly reflects $\mathrm{Ca}^{2+}$ entry into vacant stores. However, when these are full, the DRG soma appears to be able to cope with the remaining load only very slowly. In contrast, if storage sites have been vacated by using caffeine or BK, then once the $\mathrm{Ca}^{2+}$ released has been disposed of, presumably by expulsion from the cell, buffering of a depolarization-induced $\mathrm{Ca}^{2+}$ load can occur more rapidly.

Another observation we have made relates to the degree of increase in $\left[\mathrm{Ca}^{2+}\right]_{i}$ produced by depolarization of different portions of the DRG neuron. In rat superior cervical ganglion neurons we observed that $\mathrm{K}^{+}$depolarization increased $\left[\mathrm{Ca}^{2+}\right]_{i}$ to the same extent in all portions of the cell (Thayer et al., 1987a, b). However, this is clearly not the case in DRG neurons. In DRG cells the overall density of $\mathrm{Ca}^{2+}$ channels in the cell processes is apparently lower than in the cell soma. However, it may well be that high concentrations of of $\mathrm{Ca}^{2+}$ channels exist in certain portions of the DRG processes from which neurotransmitter release actually occurs and that they are scarce in other portions of the process. Such a question is most easily answered using imaging techniques. It is also possible that $\mathrm{Ca}^{2+}$ buffering in processes is more efficient than in the cell soma.

The increase in $\left[\mathrm{Ca}^{2+}\right]_{\mathrm{i}}$ produced by $\mathrm{BK}$ may be important in several respects. Thus, in NG108-15 cells mobilization of $\mathrm{Ca}^{2}$. from intracellular stores does lead to neurotransmitter release (Higashida, 1987). Furthermore, as a number of ionic conductances are sensitive to $\mathrm{Ca}^{2+}, \mathrm{BK}$-induced increases in $\left[\mathrm{Ca}^{2+}\right]_{\mathrm{i}}$ may help to regulate DRG excitability. It should further be noted that BK stimulates the release of DAG and arachidonic acid. The former has been observed to inhibit $\mathrm{Ca}^{2+}$ currents in DRG cells (Rane and Dunlap), and the latter can be metabolized to various eicosanoids that have been shown to alter $\mathrm{K}^{+}$channels in DRG cells through the production of further second messengers such as cyclic AMP (Weinreich, 1986; Wonderlein and Weinreich, 1986).

\section{References}

Baccaglini, P. T., and P. G. Hogan (1983) Some rat sensory neurons in culture express characteristics of differentiated pain sensory cells. Proc. Natl. Acad. Sci. USA. 80: 594-598.

Baker, P. F., and R. DiPolo (1984) Axonal calcium and magnesium homeostasis. Curr. Top. Membr. Transport 22: 195-249.

Barcenas-Ruiz, L., and W. G. Weir (1987) Voltage-dependence of intracellular $\left[\mathrm{Ca}^{2+}\right]_{\mathrm{i}}$ transients in guinea-pig ventricular myocytes. Circ. Res. 61: 148-154.

Beny, J. L., P. Brunet, and H. Huggel (1987) Interaction of bradykinin and des-Arg'-bradykinin with isolated pig coronary arteries: Mechanical and electrophysiological events. Regul. Pep., 17: 181-190.

Berridge, M. J. (1987) Inositol trisphosphate and diacyglyccrol: Two interacting second messengers. Annu. Rev. Biochem. 56: 159-195.

Berridge, M. J., C. P. Downes, and M. R. Hanley (1982) Lithium amplifies agonist-dependent phosphatidylinositol responses in brain and salivary glands. Biochem. J. 206: 587-595.

Billah, M. M., and E. G. Lapetina (1982) Rapid decrease of phosphatidylinositol 4,5-bisphosphate in thrombin-stimulated platelets. J. Biol. Chem. 257: 12705-12708.

Burch, R. M., and J. Axelrod (1987) Dissociation of bradykinin induced prostaglandin formation from phosphatidylinositol turnover in Swiss 3T3 fibroblasts: Evidence for G-protein regulation of phospholipase $A_{2}$. Proc. Natl. Acad. Sci. USA 84: 6374-6379.

Carafoli, E. (1987) Intracellular calcium homeostasis. Annu. Rev. Biochem. 56: 395-435.

Erdos, E. G. (1979) Bradykinin, kallidin and kallikrcin. In Handbook of Experimental Pharmacology, Vol. 25, Springer-Verlag, Berlin.

Ewald, D. A., H. J. G. Matthies, T. M. Perney, M. W. Walker, and R. J. Miller (1988) The effect of down regulation of protein kinase $C$ on the inhibitory modulation of dorsal root ganglion neuron $\mathrm{Ca}^{2+}$ currents by neuropeptide Y. J. Neurosci. 8: 2447-2451.

Fabiato, A., and F. Fabiato (1979) Calculator programs for computing the composition of the solutions containing multiple metals and li- 
gands used for experiments in skinned muscle cells. J. Physiol. (Paris) 75: 463-505.

Fowler, J. C., R. Greene, and D. Weinreich (1985) Two calcium sensitive spike afterhyperpolarizations in visceral sensory neurones of the rabbit. J. Physiol. (Lond.) 365: 59-75.

Francel, P. C., and G. Dawson (1986) Bradykinin induces a rapid release of inositol trisphosphate from a neuroblastoma hybrid cell line NCB-20 that is not antagonized by enkephalin. Biochem. Biophys. Res. Commun. 135: 507-514.

Francel, P. C., R. J. Miller, and G. Dawson (1987) Modulation of bradykinin induced inositol trisphosphate release in a novel neuroblastoma $\times$ dorsal root gangliion sensory neuron cell line $(\mathrm{F}-11)$. J. Neurochem. 48: 1632-1639.

Freedman, J. E., and G. K. Aghanjanian (1987) Role of phosphoinositide metabolites in the prolongation of afterhyperpolarizations by $\alpha_{1}-$ adrenoceptors in rat dorsal raphe neurons. J. Neurosci. 7: 3897-3906.

Griendling, K. K., S. E. Rittenshouse, T. A. Brock, L. S. Ekstein, M. A. Gimbrone, Jr., and R. W. Alexander (1986) Sustained diacylglycerol formation from inositol phospholipids in angiotensin II-stimulated vascular smooth muscle cells. J. Biol. Chem. 261: 5901-5906.

Grynkiewicz, G., M. Poenie, and R. Y. Tsien (1985) A new generation of $\mathrm{Ca}^{2+}$ indicators with greatly improved fluorescence properties. $\mathrm{J}$. Biol. Chem. 260: 3440-3450.

Higashi, H., N. Ueda, S. Nishi, J. P. Gallagher, and P. Shinnick-Gallagher (1982) Chemoreceptors for serotonin (5-HT), acetylcholine (ACh), bradykinin (BK), histamine $(\mathrm{H})$ and $\gamma$-aminobutyric acid (GABA) on rabbit visceral afferant neurons. Brain Res. Bull. 8: 2332.

Higashida, H. (1987) Presynaptic role of inositol-1,4-trisphosphate and diacylglycerol in bradykinin induced acetylcholine release at NG108-15 neuroblastom hybrid myotube synapses. Soc. Neurosci. Abstr. 13: 67.

Higashida, H., and D. A. Brown (1986a) Membrane current responses to intracellular injections to inositol-1,3,4,5-tetrakisphosphate and inositol-1,3,4-trisphosphate in NG108-15 hybrid cells. FEBS. Lett. 208: 283-286.

Higashida, H., and D. A. Brown (1986b) Two polyphosphatidylinositide metabolites control two $\mathrm{K}^{+}$-currents in a neuronal cell. Nature 323: 333-335.

Higashida, H., and D. A. Brown (1987) Bradykinin inhibits potassium (M) currents in N1E-115 neuroblastoma cells. FEBS Lett. 220: 302306.

Higashida, H., R. A. Streaty, W. Klee, and M. Nirenberg (1986) Bradykinin-activated transmembrane signals are coupled via $\mathrm{N}_{\mathrm{o}}$ or $\mathrm{N}_{\mathrm{i}}$ to production of inositol-1,4,5-trisphosphate, a second messenger in NG108-15 neuroblastoma-glioma hybrid cells. Proc. Natl. Acad. Sci. USA 83: 942-947.

Hong, S. L., and D. Deykin (1982) Activation of phosphoslipases $A_{2}$ and $\mathrm{C}$ in pig aortic endothelial cells synthesizing prostacyclin. J. Biol. Chem. 257: 7151-7154.

Irvine, R. F., and R. M. Moore (1986) Microinjection of inositol 1,3,4,5-tetrakisphosphate activates sea urchin eggs by a mechanism dependent on externala $\mathrm{Ca}^{2+}$. Biochem. J. 240: 917-920.

Jackson, T. R., T. J. Hallam, C. P. Downes, and M. R. Hanley (1987) Receptor coupled events in bradykinin action: Rapid production of inositol phosphates and the regulation of cytosolic free $\mathrm{Ca}^{2+}$ in a neural cell line. EMBO J., 6: 49-54.

Jia, M., and P. G. Nelson (1986) Calcium currents and transmitter output in cultured spinal and dorsal root ganglion neurones. J. Neurophysiol. 56: 1242-1256.

Kanaide, H., Y. Shogakiuchi, and M. Nakamura (1987) The norepinephrine-sensitive $\mathrm{Ca}^{2+}$-storage site differs from the caffeine-sensitive site in vascular smooth muscle of the rat aorta. FEBS Lett. 214: 130134.

Kuba, K. (1980) Release of calcium ions linked to the activation of a potassium conductance in a caffeine treated sympathetic neurone. $J$. Physiol. (Lond.) 298: 251-269.

Lipscombe, D., D. V. Madison, M. Poenie, H. Reuter, R. Y. Tsien, and R. W. Tsien (1987) Spatial distribution of calcium channels and cytosolic calcium transients in growth cones and cell bodies of sympathetic neurones. Proc. Natl. Acad. Sci. USA 85: 2398-2402.

Manning, D. C., and S. H. Snyder (1983) [ $\left.{ }^{3} \mathrm{H}\right]$-bradykinin in receptor localization in spinal cord and sensory ganglia, evidence for a role in primary afferent function. Soc. Neurosci. Abstr. 9: 590.
Manning, D. C., S. H. Snyder, J. F. Kachur, R. J. Miller, and M. Field (1982) Bradykinin receptor mediated chloride secretion in intestinal function. Nature 299: 256-259.

Manning, D. C., R. Vavrek, J. M. Stewart, and S. H. Snyder (1986) Two bradykinin binding sites with picomolar affinities. J. Pharmacol. Exp. Ther. 237: 504-512.

Matthies, H., H. C. Palfrey, L. D. Hirning, and R. J. Miller (1987) Down regulation of protein kinase $\mathrm{C}$ in neuronal cells: Effects on neurotransmitter release. J. Neurosci. 7: 1198-1206.

Miller, R. J. (1987a) Multiple calcium channels and neuronal function. Science 235: 46-52.

Miller, R. J. (1987b) Bradykinin highlights the role of phospholipid metabolism in the control of nerve excitability. Trends Neurosci. 10: 226-228.

Miller, R. J. (1988) G-proteins flex their muscles. Trends Neurosci. 11: 3-6.

Morris, A. P., D. V. Gallacher, R. F. Irvine, and O. H. Petersen (1987) Synergism of inositol trisphosphate and tetrakisphosphate in activating $\mathrm{Ca}^{2+}$ dependent $\mathrm{K}^{+}$channels. Nature 330: 653-655.

Murphy, S. M., S. A. Thayer, and R. J. Miller (1987) Effects of excitatory amino acids on $\left[\mathrm{Ca}^{2+}\right]_{i}$ on single striatal neurons. J. Neurosci. 7: 4145-4158.

Neering, I. R., and R. W. McBurney (1984) Role for microsomal Ca storage in mammalian neurones. Nature 309: 158-160.

Osugi, T., T. Imaizumi, A. Mizushima, S. Uchida, and Y. Yoshida (1986a) 1-oleoyl-2-acetyl-glycerol and phorbol diester stimulate $\mathrm{Ca}^{2+}$ influx through $\mathrm{Ca}^{2+}$ channels in neuroblastoma $\times$ glioma hybrid NG108-15 cells. Eur. J. Pharmacol. 126: 47-51.

Osugi, T., S. Uchida, T. Imaizumi, and H. Yoshida (1986b) Bradykinin induced intracellular $\mathrm{Ca}^{2+}$ elevation in neuroblastoma $\times$ glioma hybrid NG108-15 cells: Relationship to the action of inositol phospholipid metabolites. Brain Res., 379: 84-89.

Perney, T. M., L. D. Hirning, S. E. Leeman, and R. J. Miller (1986) Multiple $\mathrm{Ca}^{2+}$ channels mediate neurotransmitter release from peripheral neurones. Proc. Natl. Acad. Sci. USA 83: 6656-6659.

Rane, S. G., and K. Dunlap (1986) Kinase C activator 1,2-oleoylacetylglycerol attenuates voltage dependent calcium current in sensory neurones. Proc. Natl. Acad. Sci. USA 83: 184-188.

Rang, H., and J. M. Ritchie (1987) Activation of protein kinase C causes a depolarization of the rat vagus nerve associated with increased sodium conductance. J. Physiol. (Lond.) 391: 789.

Reiser, G., and B. Hamprecht (1985) Bradykinin causes a transient rise of intracellular $\mathrm{Ca}^{2+}$ activity in cultured neuronal cells. Pfluegers Arch. 405: 260-264.

Shah, J., R. S. Cohen, and H. C. Pant (1987) Inositol trisphosphateinduced calcium release in brain microsomes. Brain Res. 419: 1-6.

Thayer, S. A., L. D. Hirning, and R. J. Miller (1987a) The distribution of multiple types of $\mathrm{Ca}^{2+}$ channels in rat sympathetic neurones in vitro. Mol. Pharmacol. 32: 579-586.

Thayer, S. A., L. D. Hirning, K. M. Harris, and R. J. Miller (1987b) Distribution of multiple $\mathrm{Ca}^{2+}$ channel types and intracellular $\mathrm{Ca}^{2+}$ stores in single central and peripheral neurons. Soc. Neurosci. Abstr. 13: 1010 .

Thayer, S. A., M. Sturek, and R. J. Miller (1988) Measurement of neuronal $\mathrm{Ca}^{2+}$ transients using simultaneous microfluorimetry and electrophysiology. Pfluegers Arch. 412: 216-223.

Van Calker, D., and R. Heumann (1987) Nerve growth factor potentiates the agonist stimulated accumulation of inositol phosphates in PC-12 pheochromocytoma cells. Eur. J. Pharmacol. 135: 259-260.

Weinreich, D. (1986) Bradykinin inhibits a slow spike afterhyperpolarization in visceral sensory afferents. Eur. J. Pharmacol. 132: 6163.

Wonderlein, W. F., and D. Weinreich (1986) $\mathrm{Ca}^{2+}$ dependent outward currents activated by $\mathrm{Ca}^{2+}$ injection in visceral sensory neurones. Soc. Neurosci. Abstr. 12: 1200.

Yaksh, T. L., and D. L. Hammond (1982) Peripheral and central substrates involved in the transmission of nociceptive information. Pain 13: 1-46.

Yano, K., H. Higashida, R. Inoue, and Y. Nozawa (1984) Bradykinin induced rapid breakdown of phosphatidylinositol 4,5, bisphosphate in neuroblastoma $\times$ glioma hybrid NG108-15 cells. J. Biol. Chem. 259: 10201-10207. 